\title{
AKTYAПЬHA TEMA
}

\section{Від редакції}

У матеріалах иієї рубрики підносяться актуальні питання новітніх напрямів розвитку географічної науки. Йдеться про певне зближення економіки з наукою про довкілля людини, про формування інвайронментальної економіки як міждисииплінарного напряму. Акиентується увага на дослідженнях украйнських учених з питань розвитку інвайронменталізму та ролі географії у иьому процесі.

Представлені також напрацювання російських дослідників з важливих питань, які набувають дедалі більшої ваги з розвитком техніки і технологій, а також у зв'язку зі зростанням запитів суспільства на об'єктивну інформащію, - про нагальну потребу розширення й поглиблення кількісної інформачії у географічних дослідженнях на сучасному етапі розвитку як природничо-географічних, так $і$ суспільногеографічних наук. Йдеться про иілу систему метризації досліджуваних об'єктів, про кількісні просторово-часові оцінки компонентів природного середовища, населення, господарства $і$ m.n., які мають відображати їхні характерні риси, властивості, процеси, щзо в них відбуваються, з урахуванням взаємозв'язку та взаємозумовленості усіх їхніх компонентів.

УДК $911.3+551$

\section{І.Г. Черваньов ${ }^{1}$, Н.В. Грищенко ${ }^{2}$ ІНВАЙРОНМЕНТАЛІЗМ У СВІТОВІЙ НАУЦІ: ЗНАЧЕННЯ ДЛЯ ВІТЧИЗНЯНОї ГЕОГРАФІЇ}

\author{
И.Г. Черванев ${ }^{1}$, Н.В. Грищенко \\ ИНВАЙРОНМЕНТАЛИЗМ В МИРОВОЙ НАУКЕ: ЗНАЧЕНИЕ ДЛЯ ОТЕЧЕСТВЕННОЙ ГЕОГРАФИИ \\ ${ }^{1}$ Харьковский национальный университет имени В.Н. Каразина \\ ${ }^{2}$ Университет Корвинус, Будапешт, Венгрия \\ В статье изложены основные проблемы интеграции экономики и инвайронментологии, на фоне которых \\ выделены направления развития и конструктивная роль географии. Обозначены предпосылки возникновения \\ инвайронментальной экономики на пересечении экономики и экологии. Показано, что проблема определения места \\ экономической подсистемы в исследованиях, привела к возникновению экологической экономики. \\ Выделены основные методологические подходы инвайронментальной экономики. Перечислены главные практические \\ и теоретико-методологические направления современных исследований. Отмечены главные аспекты современных \\ инвайронментальных исследований в Украине.
}

Ключевые слова: инвайронментальная экономика; география; методологические подходы; направления исследований.

\section{Chervaniov ${ }^{1}$, N. Grishchenko ${ }^{2}$ \\ ENVIRONMENTALISM IN THE WORLD SCIENCE: NATIONAL GEOGRAPHY IMPLICATIONS \\ ${ }^{1}$ V. Karazin Kharkiv National University ${ }^{1}$ \\ ${ }^{2}$ Corvinus University, Budapest, Hungary ${ }^{2}$}

The article describes the main issues in economics and environmentology integration, with geography's constructive role and directions of its development highlighted in the background. Some prerequisites for environmental economics emergence at the intersection ecology and economics have been pointed out. It has been shown that the problem of determining the economic subsystem place in the research led to the emergence of environmental economics. The main methodological approaches of environmental economics have been highlighted. The main practical and theoretical-methodological directions of the modern research have been listed. The main aspects of modern environmental research in Ukraine have been marked. Keywords: environmental economics, geography, methodological approaches, research directions.

\section{Вступ}

Понад 10 років тому на VIII з'їзді Українського географічного товариства в колективній пленарній доповіді було піднято питання новітніх тенденцій розвитку географічної науки [6]. Серед інших обговорювалося й питання інвайронментології (інвайрологіï) як напряму географії, націленого на пізнання «людської оселі» в розумінні К.Ріттера. Це було відгуком на те, що у західному світі стало очевидним ще на початку 20-х рр. минулого століття, коли відомий англійський економіст А.Пігу запровадив до 
економічної теорії блок інвайронментальних проблем [15]. Постановка такого питання викликала значний інтерес з боку економістів, спонукала їх враховувати позаекономічні цінності людського багатства (екстерналії). Відповідно, представники природничих наук також опинилися перед проблемою зменшення негативного впливу розвитку економіки (економічного зростання) на природу.

Вищим вираженням цієї тенденції, в якій поєдналися інтереси охорони довкілля й економічного розвитку, став саміт в Ріо-де-Жанейро у 1992 р., який запропонував концепцію сталого розвитку. Вона отримала значний відгук і в українській географічній літературі. У руслі цих досліджень виникла інвайронментальна економіка - Environmental Economics (IE).

Короткий виклад іï передумов та історію розвитку викладено в роботі [13], частково - у $[2,9,10]$. Оскільки проблеми, що постали перед ученими, $є$ міждисциплінарними, то не дивно, що IЕ зародилася на перетині двох наукових напрямів світової науки: економічного та екологічного.

М е т а цієї публікації - розглянути сучасний стан інтеграції економіки з наукою про довкілля людини - інвайронментологією, показавши на цьому тлі напрями розвитку вітчизняної географії.

У роботі використано аналіз публікацій з інвайронментальної та екологічної економіки за світовими базами наукових баз знань Science Direct i Springer Database, за 2001 - 2012 рр., включаючи препринти поточного року (проте, останні не дають повної картини таких публікацій).

\section{Аналіз світових тенденцій інвайронменталізму}

Якнайповніше питання інтеграції економіки та екології описав Герман Дейлі [13]. 3 появою саме цього наукового напряму виникли деякі складнощі, зумовлені міждисциплінарністю досліджень та їхньою різнобічною практичною спрямованістю, розгорнулася певна наукова дискусія щодо місця, яке займає в дослідженнях економічна підсистема.

Частина учених (наприклад, І. Фодор [14], Р. Констанца, Г. Дейлі та інші [11]) визначили місце економіки як підсистеми інвайронментології, при цьому фактично було обгрунтовано виникнення екологічної економіки (ЕЕ). Це сталося у відповідь на проголошення економістами екологічних проблем такими, що притаманні економічній підсистемі. Виникла ситуація конфлікту між представниками наукових шкіл інвайронментальної економіки та екологічної економіки. Внаслідок цього, межа сфер досліджень обох напрямів і базові методологічні підходи досліджень стали виділятися чіткіше. Г. Дейлі сформулював визначення IE: інвайронментальна економіка - відгалуження неокласичної економіки, яке займається вивченням таких проблем довкілля, як забруднення, негативні зовнішні ефекти (екстерналії) та оцінка неринкових иінностей довкілля [13, с. 484]. Наведене вище визначення, напевно, не є остаточним, оскільки IE - відносно молодий напрям досліджень, що лише формується, розвиваючись у рамках концепції «слабкої» стійкості [9].

У контексті використання ресурсів IE дає альтернативні варіанти економічного розвитку через активізацію природних систем (природного капіталу) з меншою кількістю обмежень, ніж за вимоги «сильної» стійкості. У IE ресурси оцінюються в сумі, комплексно, як територіальний ресурс у нашому розумінні. Отже, допускається можливість і зростання, і зменшення або заміщення природного капіталу. У вітчизняній літературі це викладено, зокрема, у публікаціях $[2,3,9,10]$.

Вважають, що неокласичний підхід, який знаходиться в основі досліджень IE, за своєю суттю є підходом економічного імперіалізму, тому що характеризується експансією поза своїми власними кордонами. Тобто апологети IE прагнуть знайти способи розширення межі економічної підсистеми, аж доки екологічна підсистема не стане іiі частиною. Натомість, обговорюється етична дилема: чи має наука моральне право створювати єдину глобальну економічну макросистему, грунтуючись лише на тому, що все має свою вартість, має бути оцінене і виведене на ринок? Як у такому разі бути з неекономічними вартостями: естетичними, історико-культурними, сакральними, які часто важать для конкретних людей істотно більше ніж гроші?

Ці питання ще потребують концептуального опрацювання та імплементації в діючу економічну систему, і конструктивна роль географії в цьому відношенні може бути далеко не ар'єргардною.

\section{Оцінка динаміки інвайронментологічних публікацій}

За результатами аналізу бази знань Science Direct i Springer Database, кількість публікацій з тематики IE зростає експоненціально. Наприклад, в Springer Database (веде облік з 1924 р.) кількість публікацій за темою майже за 90 років зросла більш ніж в 3000 разів, і сьогодні вони складають $0,51 \%$ від загальної кількості матеріалів, занесених у базу з усіх галузей знання (таких близько 7 млн одиниць). 
Основними напрямами досліджень залишаються практичні аспекти використання методів і підходів IE, серед яких слід виділити такі [19]:

- $\quad$ оцінювання впливу економіки на довкілля (розроблення і удосконалення індикаторів для оцінки впливу людини на довкілля);

- $\quad$ оцінювання вартості природних ресурсів і природного капіталу (особливо економічна оцінка нематеріальних ресурсів);

- $\quad$ визначення ролі технологій та інноваційного процесу у взаємовідносинах у системі суспільство - економіка - довкілля (вирішення проблем забруднення, розробка систем запобігання забрудненню, підвищення ефективності використання ресурсів).

Оскільки теоретичні основи IE розроблені недостатньо, то поряд з великою кількістю практичних досліджень проводяться теоретико-методологічні вишукування, а саме:

- формулювання міждисциплінарних підходів щодо досліджень довкілля;

- уточнення місця IЕ в системі наукових дисциплін;

(зокрема, оцінка взаємозв' язків між економічним зростанням і рівнем забруднення; проблема задоволення попиту на ресурси при підвищенні ефективності виробництва; наявність і характер взаємозв'язку між інституційним регулюванням і зменшенням впливу на довкілля);

- розроблення й удосконалення теоретичних аспектів раціонального природокористування;

- освіта в цілях стійкого розвитку.

Основними напрямами впровадження IE у практику є галузі контролю і розробки інвайронментальних стандартів та новостворювана інвайронментальна індустрія (environmental industry, ecological industry, ecoindustry). Про інвайронментальну індустрію (II), стали говорити в другій половині 90-х років минулого століття, визнавши, що вона певною мірою є прикладною інвайронментальною економікою.

На відміну від власне IE, існує досить поширене визначення II, прийняте Європейською Комісією в 1994 р., яке використовує Організація Економічного співробітництва і розвитку [20]. При цьому, слід зазначити, що II і еко-індустрія вважаються тотожними поняттями. Інвайронментальна індустрія включає діяльність 3 виробництва товарів і надання сервісу для вимірювання, запобігання, обмеження, мінімізації або корегування збитку від забруднення води, повітря і грунту, а також для вирішення проблем, пов'язаних 3 відходами, шумом та іншими чинниками негативного впливу на екосистеми.

Окремо розглядається питання «м'якого» управління в системі суспільство - економіка - довкілля, тобто інвайронментального менеджменту (IM). Основною його метою є зменшення шкідливого впливу на довкілля при використанні існуючої технології та збереженні, наскільки це можливо, економічної доцільності [12]. При цьому, підкреслюється першочерговість економічної складової, яка й забезпечує економічне зростання та поліпшення якості життя.

Питання якості життя при дотриманні нинішніх темпів економічного розвитку $є$ дуже гострим. Наприклад, за даними HSBC Grobal Research [20], збільшення об'єму економіки України до 2050 р. прогнозується в 9,7 разів. Що необхідно зробити сьогодні в плані інвайронментального менеджменту? Як це вплине на якість життя? Зазначимо, що такого ж роду питання висвітлюються і в монографії [5]. Від правильності прийнятих рішень на рівні держав, органів місцевого самоврядування та компаній залежатиме якість довкілля, в якому житимуть майбутні покоління.

\section{Аспекти вітчизняних досліджень}

Українські вчені пропонують реальні варіанти розвитку інвайронменталізму, в тому числі через конкретизацію завдань і мобілізацію можливостей «нової» географії при збереженні прагнення до стійкого розвитку $[1,8]$.

Л.Г. Руденко на основі аналізу світових тенденцій сучасного суспільства пише про конвергенцію економіки та економічної географії, відзначаючи: «Многие экономисты начали использовать географические методы исследований и переходят на изучение объектов, не свойственных для экономики, - пространства, соседства, тесноты связей. Происходит сближение экономической географии и экономики [8, с. 41$]$.

М.В.Багров висунув парадигму стійкісно-ноосферного розвитку, показавши на багатому регіональному матеріалі, як можна впроваджувати паростки ноосферного розвитку на прикладах раціональної організації адміністративних районів і поселень Криму. Такі роботи виконані Центром сталого розвитку Таврійського національного університету імені В.І.Вернадського. Як показав учений у завершальній главі монографії, присвяченій науково-освітнім і просвітницьким аспектам стійкісно-ноосферної парадигми, 
«... Общество не сможет выжить без знаний о доме своего проживания - планете Земля, но они (знания - И.Ч., Н.Г.) могут терять всякий смысл, если люди не смогут найти механизмы согласования своего поведения с законами гармонизации отношений в системе «природа-общество».... Примирить эти позиции сможет система ноосферизации образования, чему способствует стремительная ноосферизация современного общества» [2, с. 180-181]. Учений зазначає, що дослідження процесу ноосферогенезу потребує мультидисциплінарного наукового супроводу і висловлює припущення про зародження нового напряму - соціоноосферної географії, зміст і головні завдання якої викладає в публікації [4].

\section{Висновок}

Викладене дає підстави для висновку про те, що зближення економіки з географією і практикою, яке нині спостерігається, може бути корисним для всіх учасників цього процесу: економіка стає людиновимірною [6], отримуючи до того ж ренту як джерело сталого розвитку, географія - більш конструктивною наукою про території як природний капітал та інтегральний ресурс стійкісно-ноосферного розвитку [1], а практика - природозбережувальною [2].

\section{Лumepamypa}

1. Багров Н.В, Руденко Л.Г., Черванев И.Г. «Новая» география в украинских реалиях: миссия и тренды развития // Изв. РАН. Сер. географ. - 2012. - № 4. - С.7-19.

2. Багров М.В., Костріков С.В., Черваньов І.Г. До питання формалізації інвайронментального виміру сталого соціальноекономічного розвитку суспільства // Культура народов Причерномор'я. - 2009. - № 1 -2. - С. 8-14.ь

3. Багров Н.В. Устойчиво-ноосферное развитие региона. Проблемы. Решения. - Симферополь: ТНУ им. В.И.Вернадского. 2010. $-207 \mathrm{c}$.

4. Багров Н.В. Парадигма современной географи: от ретроспекции к соционоосферному направлению // Укр. геогр. журн. 2011. - № 2. - C. 10 - 15 .

5. Гукалова І.В. Якість життя населення України: суспільно-географічна концептуалізація. - К., 2009. - 346 с.

6. Задорожний Г.В., Колупаєва I.В. Людська діяльність: зміст і трансформація структури у сучасному господарському розвитку. - Харків, 2009. - $158 \mathrm{c}$.

7. Руденко Л.Г., Олещенко В.І., Черваньов І.Г. Географічна наука на рубежі століть // Україна та глобальні процеси: географічний вимір / Матеріали. IX з'їзду УГТ. - К.-Луцьк: Вежа, 2000.

8. Руденко Л.Г. Новые задачи географии на пути к информационному обществу / Новые географические знания и направления исследований. - К.: ИГ НАН Украины, МААН, 2006. - С. 3 - 43.

9. Черванев И.Г., Боков В.А. Качество природы как потребительская стоимость (основы инвайронментальной экономики) // Культура народов Причерноморья. - 2001. - № 1. - С. 63 - 78.

10. Черванев И.Г., Грищенко Н.В. Инвайронментальная экономика: методология, подходы и конструктивные направления // Социальная экономика. - 2012. - № 4. - С. 169 - 179.

11. Costanza R., Cumberland J., Daly H. An Introduction to Ecological Economics: St. Lucie Press, 1997. - 288 p.

12. Cricker T.D. A short story of environmental and resource economics / Handbook of environmental and resource economics. Cheltenham: Edward Elgar, 1999. - P. 32 - 45.

13. Daly H.E., Farley J., Ecological Economics: Principles and Applications: Island Press, 2010 - Secodition. - 539 p.

14. Fodor I., Suvak A. The role of environmental industry in sustainable economic development // The role of environmental industry in the regional reindustrialisation in Hungary. - Debrecen-Pecs : Hungarian Academy of Sciences Centre for Regional Studies - 2009. - P. $35-51$.

15. Pigou A.C. The Economics of Welfare. - London: Macmillan and Co,- 1920. -876 p.

16. Schaltegger S., Burrit R., Petersen H.An Introduction to Corporate Environmental Management: Striving for Sustainability. - L.: Greenleaf Publishing Lm. - 2003.

17. Sollner F. A reexamination of the role of thermodynamics for environmental economics // Ecological Economics. - 1997. - 22. - P. $175-201$.

18. Venkatachalam L. Environmental economics and ecological economics: Where they can converge?// Ecological Economics. -2007. -61 . - P. $550-558$.

19. The Global Environmental Goods and Services Industry OECD report. - mode access: www.oecd.org/dataoecd/11/10/2090577.

20. The World in 2050: From the Top 30 to the Top 100 / HSBC Grobal Research. - 2012 - mode access: http://www.hsbc.com.mx/1/ PA_esf-ca-app-content/ content/home/empresas/archivos/world_2050.

${ }^{1}$ Харківський національний університет імені В.Н.Каразіна

${ }^{2}$ Університет Корвінус, Будапешт, Угорщина 